\title{
Deposition Condition of Epitaxially Grown PZT Films by CVD
}

\author{
Hiroshi FUNAKUBO, Katsuhiro IMASHITA, Katsumi MATSUYAMA, \\ Kazuo SHINOZAKI and Nobuyasu MIZUTANI \\ Department of Inorganic Materials, Faculty of Engineering, Tokyo Institute of Technology, 2-12-1, O-okayama, Meguro-ku, Tokyo 152
}

\author{
CVD 法によるエピタキシャル成長 PZT 薄膜の析出条件 \\ 舟窪 浩・今下勝博・松山勝美・篠﨑和夫・水谷惟恭 \\ 東京工業大学工学部無機材料工学科, 152 東京都目黒区大岡山 2-12-1
}

[Received February 28, 1994; Accepted May 19, 1994]

\begin{abstract}
Epitaxially grown $\mathrm{Pb}(\mathrm{Zr}, \mathrm{Ti}) \mathrm{O}_{3} \quad[\mathrm{PZT}]$ films were deposited on (100) MgO substrates by CVD and the effects of deposition parameters on the epitaxial growth of the films were investigated. The films consisting of $\mathbb{P Z T}$ single phases were deposited from about 0.4 to 0.5 of $\mathrm{Pb} /(\mathrm{Pb}+\mathrm{Zr}+\mathrm{Ti})$ and the epitaxially grown film was obtained near 0.5 of $\mathrm{Pb} /(\mathbf{P b}+\mathrm{Zr}+\mathrm{Ti})$. Epitaxially grown PZT films were deposited over wide deposition conditions; $600-700^{\circ} \mathrm{C}$ of the deposition temperature, $1.1-6.7 \mathrm{kPa}$ of the total gas pressure and 64 $\mathrm{Pa}=1.1 \mathrm{kPa}$ of the oxygen partial pressure.
\end{abstract}

Key-words : CVD, PZT film, Epitaxial film, Deposition parameter

\section{Introduction}

$\mathrm{Pb}(\mathrm{Zr}, \mathrm{Ti}) \mathrm{O}_{3}, \mathrm{PZT}$, films have been recognized to have very wide applications including electronic devices with high performance. PZT films has been prepared by various methods, such as evaporation and sputtering. The sputtering method is the most widely accepted deposition technique for the preparation of PZT film. However, the problem of the difficulty of the control of composition has been pointed out. $\mathrm{Pb}$ content in the film fairly depends on the deposition conditions, such as deposition temperature and deposition pressure. ${ }^{1)}$

On the other hand, CVD is the potential method for the preparation of this film because the precise control of film composition and crystallinity is expected to be relatively ease.2)-4) Okada et al.2) reported the deposition temperature and the oxygen partial pressure dependence of the deposition rates of $\mathrm{PbO}$, $\mathrm{ZrO}_{2}$ and $\mathrm{TiO}_{2}$ films from $\mathrm{Pb}\left(\mathrm{C}_{3} \mathrm{H}_{5}\right)_{2}-\mathrm{O}_{2}, \mathrm{Zr}(\mathrm{DPM})_{4}{ }^{-}$ $\mathrm{O}_{2}$ and titanium tetra-isopropoxide $\left[\mathrm{Ti}\left(\mathrm{O} \cdot i-\mathrm{C}_{3} \mathrm{H}_{7}\right)_{4}\right.$, $\left.\mathrm{Ti}(\mathrm{O} \cdot i-\mathrm{Pr})_{4}\right]-\mathrm{O}_{2}$ systems, respectively. However, the deposition condition of epitaxially grown PZT film by CVD has been hardly reported.

We have already reported the preparation and the characterization of epitaxially grown PZT films on (100) MgO substrates by CVD.5),6) In the present study, we describe the effects of the composition, the deposition temperature and the total gas pressure on the constituent phase, the crystallinity and the texture of the film.

\section{Experimental procedure}

PZT films were deposited on (100) MgO substrates from the gas mixture of bis (dipivaloylmethanato) lead $\left[\mathrm{Pb}\left(\mathrm{C}_{11} \mathrm{H}_{19} \mathrm{O}_{2}\right)_{2}, \mathrm{~Pb}(\mathrm{DPM})_{2}\right]$, tetratertiary butoxyzirconium $\left[\mathrm{Zr}\left(\mathrm{O} \cdot t-\mathrm{C}_{4} \mathrm{H}_{9}\right)_{4}, \mathrm{Zr}(\mathrm{O}\right.$. $t$-Bu $\left.)_{4}\right], \quad \mathrm{Ti}(\mathrm{O} \cdot i \text {-Pr })_{4}$ and $\mathrm{O}_{2}$, which was already reported in the previous paper.6) (100) $\mathrm{MgO}$ single crystal was used as a substrate.

The deposition conditions are summarized in Table 1. In the present study, we examined the effect of the deposition temperature, the total gas pressure and the input gas composition under the other deposition parameters fixed. For this purpose, the standard condition was defined as shown in Table 1 . In this standard condition, the epitaxially grown PZT films were deposited as described in the previous paper. ${ }^{6}$ )

The constituent phase and the orientation of the films were identified by X-ray powder diffraction (XRD; Philips, PW-1700). We used the full width of a half maximum intensity (FWHM), $\beta_{1 / 2}$, of (003) reflection for the estimation of crystallinity of PZT phase. The peak position of this peak is independent of the compositional fluctuation of $\mathrm{Zr} /(\mathrm{Zr}+\mathrm{Ti})$ in PZT phase, because the $c$-axis lattice parameter of PZT is almost independent of $\left.\mathrm{Zr} /(\mathrm{Zr}+\mathrm{Ti}) .{ }^{7}\right)$ The texture of the $c$-axis oriented PZT film was measured. by using an X-ray pole figure device (Philips, PW1078/50). The structural arrangements of the crystal perpendicular and parallel to the substrate can be estimated from (001) and (101) X-ray pole figures, respectively.

The composition of the film was measured by EDS (Philips, PV9900) attached to scanning electron microscopy (SEM) and defined as $\mathrm{Pb} /(\mathrm{Pb}+\mathrm{Zr}+$ Ti) and $\mathrm{Zr} /(\mathrm{Zr}+\mathrm{Ti})$.

\section{Results and discussion}

\subsection{Effect of $\mathrm{Pb}, \mathrm{Zr}$ and $\mathrm{Ti}$ contents}

Figure 1 shows the dependence of constituent phases of the film on $\mathrm{Pb}, \mathrm{Zr}$ and $\mathrm{Ti}$ contents in the film at the deposition temperature of $650^{\circ} \mathrm{C}$. The $\mathrm{Pb}$, $\mathrm{Zr}$ and $\mathrm{Ti}$ contents were varied by changing the input gas composition. As shown in Fig. 1, the constituent phase strongly depended on $\mathrm{Pb}$ content in the film, $\mathrm{Pb} /(\mathrm{Pb}+\mathrm{Zr}+\mathrm{Ti})$, and changed with the in- 
Table 1. Deposition Conditions

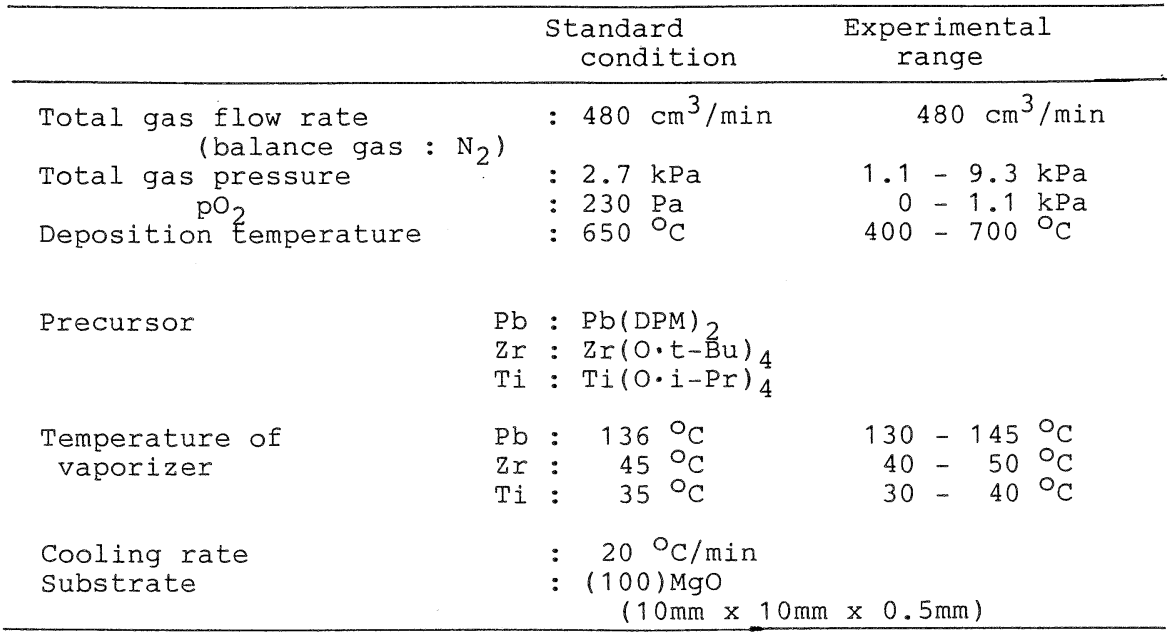

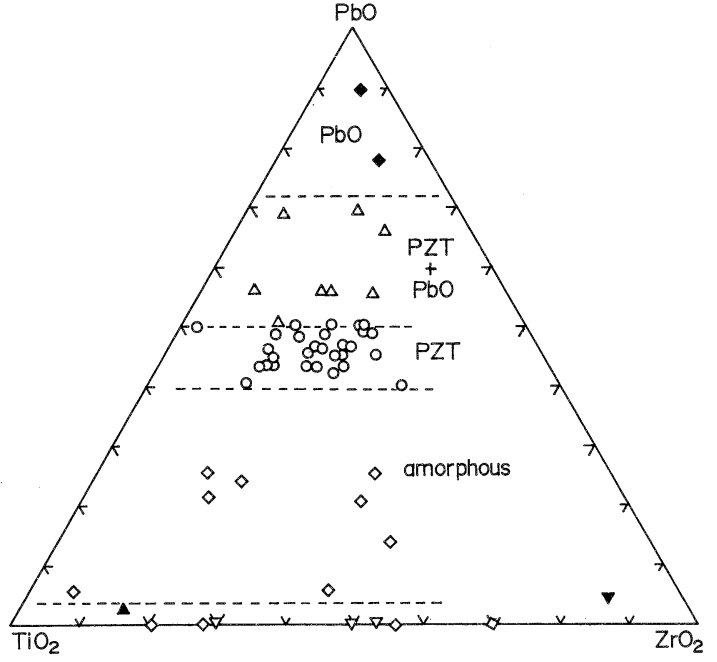

Fig. 1. Constituent phase of the film as functions of $\mathrm{Pb}, \mathrm{Zr}$ and Ti contents in the film.

$(\bigcirc) \mathrm{PZT},(\diamond) \mathrm{PbO},(\triangle) \mathrm{PZT}+\mathrm{PbO},(\nabla) \mathrm{ZrTiO}_{4},(\diamond)$ amorphous, $(\mathbf{\Lambda}) \mathrm{TiO}_{2},(\boldsymbol{\nabla}) \mathrm{ZrO}_{2}$.

crease of $\mathrm{Pb} /(\mathrm{Pb}+\mathrm{Zr}+\mathrm{Ti})$ as follows; amorphous $\rightarrow$ perovskite-type of structure $(\mathrm{PZT}) \rightarrow \mathrm{PZT}+\mathrm{PbO}$ $\rightarrow \mathrm{PbO}$. The transparent film of the single phase of the perovskite-type of structure (PZT) on XRD pattern was deposited within the range from about 0.4 to 0.5 of $\mathrm{Pb} /(\mathrm{Pb}+\mathrm{Zr}+\mathrm{Ti})$. In this region, the peak intensities of PZT phase increased with the increase of $\mathrm{Pb} /(\mathrm{Pb}+\mathrm{Zr}+\mathrm{Ti})$ and it was ascertained by $\mathrm{X}$-ray pole figure that epitaxially grown film was deposited near 0.5 of $\mathrm{Pb} /(\mathrm{Pb}+\mathrm{Zr}+\mathrm{Ti})$. Therefore, the stoichiometry of $\mathrm{Pb}$ content is the most important condition to get epitaxially grown PZT film. Below 0.4 of $\mathrm{Pb} /(\mathrm{Pb}+\mathrm{Zr}+\mathrm{Ti})$, the film still maintained good transparency but the peak of PZT was not detected on XRD pattern. Swartz et al. ${ }^{8)}$ also reported that when $\mathrm{PbTiO}_{3}$ films were prepared by CVD from $\mathrm{Pb}\left(\mathrm{C}_{2} \mathrm{H}_{5}\right)_{4}-\mathrm{Ti}(\mathrm{O} \cdot i-\mathrm{Pr})_{4}-\mathrm{O}_{2}$ system, $\mathrm{Pb}$ poor film tended to be amorphous. For PZT powder study, the single phase of PZT is reported to be obtained in the range from 0.475 to 0.5 of $\mathrm{Pb} /(\mathrm{Pb}+\mathrm{Zr}+\mathrm{Ti}){ }^{9)}$ Therefore, it is considered that the film consisting of PZT single phase on XRD pattern and with lower $\mathrm{Pb}$ content compared to the stoichiometric one, contained amorphous phase together with perovskite phase.

When a film contained excess $\mathrm{Pb}, \mathrm{PbO}$ phase was codeposited with PZT as shown in Fig. 1 and a film tended to be yellow in color. However, $\mathrm{PbO}$ peaks were very broad on XRD pattern and was hardly observed under the slight excess of $\mathrm{Pb}$ content. Therefore, the crystallinity of $\mathrm{PbO}$ phase in $\mathrm{Pb}$ excess film was thought to be very low. Chen et al. ${ }^{10)}$ also reported the low crystallinity of $\mathrm{PbO}$ phase codeposited with $\mathrm{PbTiO}_{3}$ phase when $\mathrm{Pb}$ excess film was deposited by $\mathrm{CVD}$ using $\mathrm{Pb}\left(\mathrm{C}_{2} \mathrm{H}_{5}\right)_{4}-\mathrm{Ti}(\mathrm{O} \cdot i \text { - } \mathrm{Pr})_{4}-\mathrm{O}_{2}$ as starting materials.

\subsection{Effect of oxygen partial pressure}

Figure 2 shows the effect of the oxygen partial pressure $\left(p_{\mathrm{O}_{2}}\right)$ on the composition of the film together with the constituent phase. $\mathrm{Zr} /(\mathrm{Zr}+\mathrm{Ti})$ was irrespective of $p_{\mathrm{O}_{2}}$ as shown in Fig. 2(a). On the other hand, $\mathrm{Pb} /(\mathrm{Pb}+\mathrm{Zr}+\mathrm{Ti})$ decreased under $0 \mathrm{~Pa}$ of $p_{\mathrm{O}_{2}}$, although no remarkable change was observed above $64 \mathrm{~Pa}$ as shown in Fig. 2(b). Moreover, the constituent phase of this film became amorphous on XRD pattern and the deposition rate of the film also decreased compared with that above $64 \mathrm{~Pa}$ of $p_{\mathrm{O}_{2}}$.

When $\mathrm{ZrO}_{2}$ and $\mathrm{TiO}_{2}$ films were prepared from $\mathrm{Zr}(\mathrm{O} \cdot t-\mathrm{Bu})_{4}-\mathrm{O}_{2}$ and $\mathrm{Ti}(\mathrm{O} \cdot i-\mathrm{Pr})_{4}-\mathrm{O}_{2}$ systems, respectively, their deposition rates were irrespective

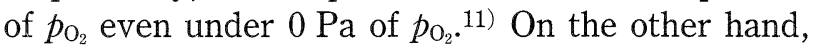
when $\mathrm{PbO}$ film was prepared from $\mathrm{Pb}(\mathrm{DPM})_{2}-\mathrm{O}_{2}$ system, its deposition rate remarkably decreased under $0 \mathrm{~Pa}$ of $p_{\mathrm{O}_{2}}$, although no remarkable change with $p_{\mathrm{O}_{2}}$ was observed above $64 \mathrm{~Pa}$ of $p_{\mathrm{O}_{2}}$. Therefore the decrease of $\mathrm{Pb} /(\mathrm{Pb}+\mathrm{Zr}+\mathrm{Ti})$ under $0 \mathrm{~Pa}$ of $p_{\mathrm{O}_{2}}$ in Fig. 2(b) is thought to be related to the different $p_{\mathrm{O}_{2}}$ dependence of the deposition rates between $\mathrm{PbO}$ films, and $\mathrm{ZrO}_{2}$ and $\mathrm{TiO}_{2}$ films. This difference must 


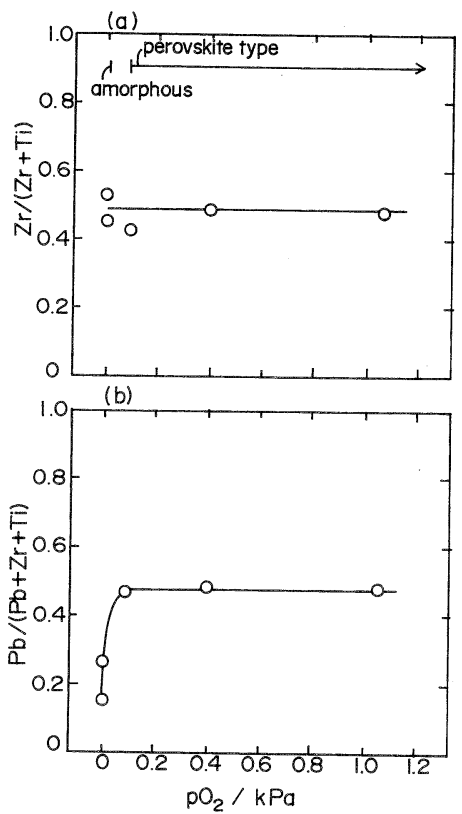

Fig. 2. The composition of the film as a function of the oxygen partial pressure.

(a) $\mathrm{Zr} /(\mathrm{Zr}+\mathrm{Ti})$, (b) $\mathrm{Pb} /(\mathrm{Pb}+\mathrm{Zr}+\mathrm{Ti})$

be attributed to the fact that $\mathrm{Zr}(\mathrm{O} \cdot t-\mathrm{Bu})_{4}$ and $\mathrm{Ti}(\mathrm{O} \cdot i \text { - } \mathrm{Pr})_{4}$ include sufficient oxygen in its structure for the preparation of $\mathrm{TiO}_{2}$ and $\mathrm{ZrO}_{2}$ films without introducing $\mathrm{O}_{2}$, respectively, although $\mathrm{Pb}(\mathrm{DPM})_{2}$ dose not include sufficient oxygen in its structure. Tominaga et al. ${ }^{12)}$ also reported that the deposition rate of $\mathrm{La}_{2} \mathrm{O}_{3}$ films prepared from $\mathrm{La}(\mathrm{DPM})_{3}-\mathrm{O}_{2}$ system decreased below $160 \mathrm{~Pa}$ of $p_{\mathrm{O}_{2}}$. On the other hand, the film deposited above $64 \mathrm{~Pa}$ of $p_{\mathrm{O}_{2}}$ consisted of the single phase of PZT and $\beta_{1 / 2}$ of PZT (003) reflections was irrespective of $p_{\mathrm{O}_{2}}$. Therefore the effect of $p_{\mathrm{O}_{2}}$ on the deposition film was not observed above $64 \mathrm{~Pa}$ of $p_{\mathrm{O}_{2}}$ within the limit of the present study.

\subsection{Effect of deposition temperature}

Figure 3 shows the change of $\mathrm{Pb} /(\mathrm{Pb}+\mathrm{Zr}+\mathrm{Ti})$ in PZT film with the deposition temperature, together with the constituent phase of the film. $\mathrm{Zr} /(\mathrm{Zr}+\mathrm{Ti})$ in the film was ascertained to be almost independent of the deposition temperature. As shown in Fig. 3,

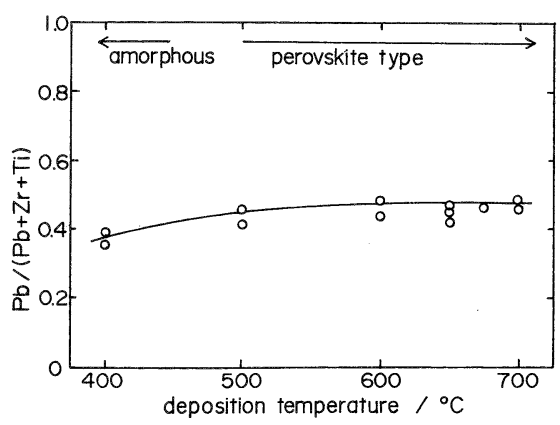

Fig. 3. Effect of the deposition temperature on $\mathrm{Pb} /$ $(\mathrm{Pb}+\mathrm{Zr}+\mathrm{Ti})$ and the constituent phase of the film. $[\mathrm{Zr} /(\mathrm{Zr}+\mathrm{Ti})=0.4]$

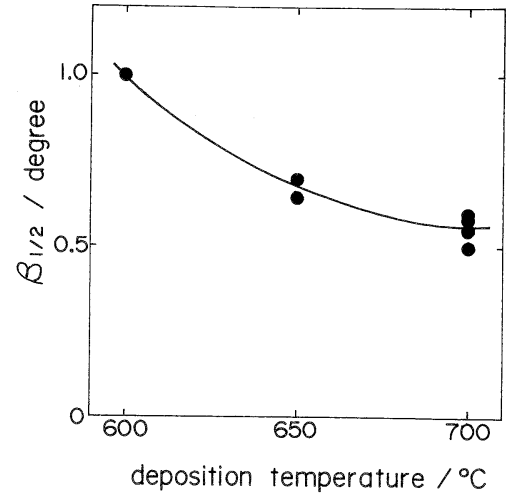

Fig. 4. Deposition temperature dependence of full width of half maximum intensity $(\mathrm{FWHM}), \beta_{1 / 2}$, of (003) reflections of PZT phase.

$[\mathrm{Zr} /(\mathrm{Zr}+\mathrm{Ti})=0.4]$

the constituent phase of the film deposited at $400^{\circ} \mathrm{C}$ was amorphous on XRD pattern, while the films deposited above $500^{\circ} \mathrm{C}$ consisted of perovskite-type of structure (PZT). Although, the film deposited at $500^{\circ} \mathrm{C}$ was polycrystalline, epitaxially grown PZT films were deposited above $600^{\circ} \mathrm{C} . \mathrm{Pb} /(\mathrm{Pb}+\mathrm{Zr}+\mathrm{Ti})$ was almost constant irrespective of the deposition temperature, although it was slightly low for the film deposited at $400^{\circ} \mathrm{C}$ as shown in Fig. 3 .

Figure 4 shows $\beta_{1 / 2}$ of (003) reflections of epitaxially grown PZT in Fig. 3 as a function of the deposition temperature. $\beta_{1 / 2}$ decreased with the increase of the deposition temperature. This result shows that the crystallinity of the film increases with the increase of the deposition temperature. From the results of Figs. 3 and 4, epitaxially grown film with high crystallinity is obtained at relatively high deposition temperature; $700^{\circ} \mathrm{C}$.

When PZT film was deposited by other methods such as sputtering and evaporation, pyrochlore phase has been reported to be deposited below the deposition temperature at which perovskite-type of structure (PZT) was deposited. ${ }^{13)}$ Moreover, $\mathrm{Pb}$ content has been reported to decrease with the increase of the deposition temperature above $650^{\circ} \mathrm{C}$, so that the control of $\mathrm{Pb}$ content was quite difficult.1) However, the film consisting of pyrochlore phase was not deposited and the composition of the films was almost independent of the deposition temperature as shown in Fig. 3 within the limit of the present study. This is attributed to the fact that CVD-deposited film is prepared under the relatively high total gas pressure and high partial pressure of $\mathrm{Pb}$ element compared with other preparation methods, so that the revaporization of $\mathrm{Pb}$ element from the film is diminished. As a result, it can be concluded that CVD has high controllability of composition and can deposit epitaxially grown film over wide deposition temperature without the deposition of pyrochlore phase.

3.4 Effect of total gas pressure

Figure 5 shows the XRD patterns of the film 


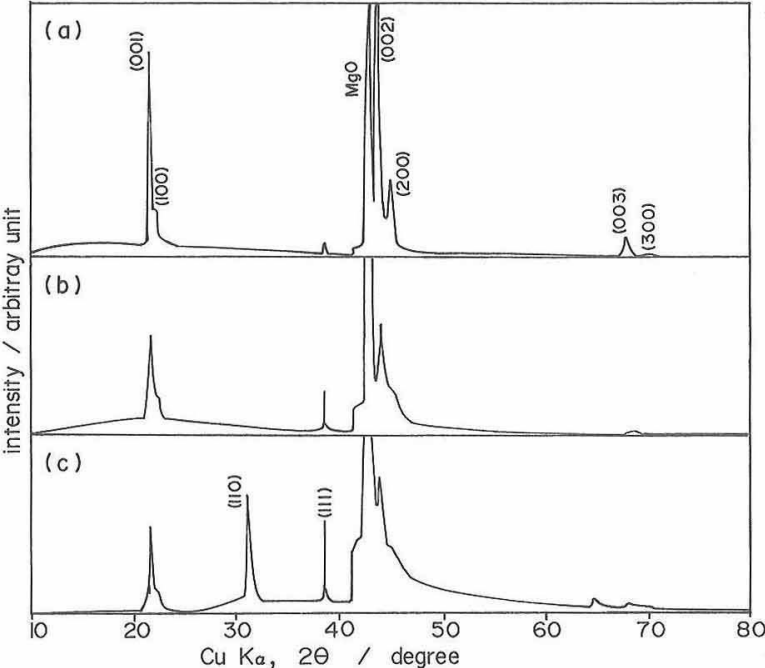

Fig. 5. XRD patterns of PZT films deposited under various total gas pressure.

$[\mathrm{Pb} /(\mathrm{Pb}+\mathrm{Zr}+\mathrm{Ti})=0.5, \mathrm{Zr} /(\mathrm{Zr}+\mathrm{Ti})=0.4]$

Total gas pressure : (a) $1.1 \mathrm{kPa}$, (b) $6.7 \mathrm{kPa}$, (c) $9.3 \mathrm{kPa}$.

deposited under various total gas pressures. The composition of all films in Fig. 5 was 0.5 of $\mathrm{Pb} /$ $(\mathrm{Pb}+\mathrm{Zr}+\mathrm{Ti})$ and 0.4 of $\mathrm{Zr} /(\mathrm{Zr}+\mathrm{Ti})$ irrespective of the total gas pressure. Only $(h 00)$ and $(00 l)$ reflections of PZT phase were observed together with those of $\mathrm{MgO}$ substrate for the film deposited under 1.1 and $6.7 \mathrm{kPa}$ as shown in Figs. 5(a) and (b). On the other hand, (110) and (111) reflections were observed on XRD pattern together with $(h 00)$ and $(00 l)$ ones for the film deposited under $9.3 \mathrm{kPa}$ as shown in Fig. 5 (c).

Figure 6 shows the (001) and (101) pole figures of the films deposited under 2.7 and $9.3 \mathrm{kPa}$. (001) and (101) pole figures of the film deposited under $2.7 \mathrm{kPa}$ shown in Fig. 6 (a) were the same described in the previous paper. ${ }^{5)}$ Moreover pole figures in Fig. 6(a) were in good agreement with that of $\mathrm{MgO}$

(OOI)

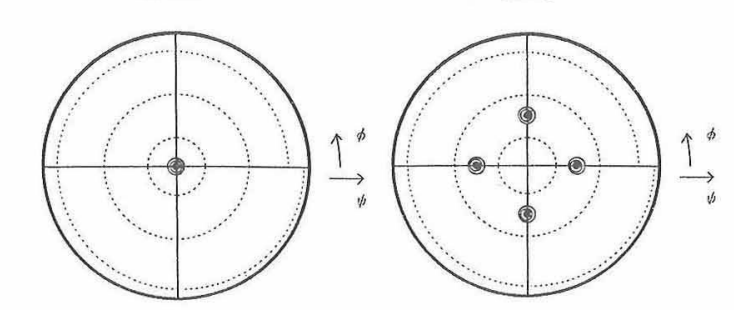

(a)

(b)
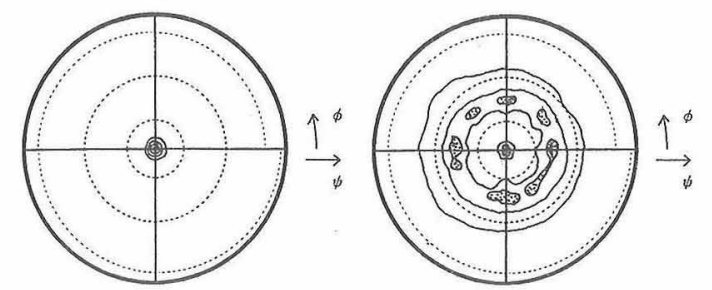

Fig. 6. (001) and (101) pole figures of the film deposited under 2.7 and $9.3 \mathrm{kPa}$.

Total gas pressure : (a) $2.7 \mathrm{kPa}$, (b) $9.3 \mathrm{kPa}$. substrate and calculated one from the lattice parameter data of this PZT phase. Therefore this result shows that this film was epitaxially grown on (100) $\mathrm{MgO}$ substrate. On the other hand, (001) pole of the film deposited under $9.3 \mathrm{kPa}$ was slightly broadened along $\psi$ compared with that of the film shown in Fig. 6(a). This broadening indicated that the degree of $c$-axis orientation was lower than that of the film shown in Fig. 6(a). On the other hand, (101) poles diffused along $\phi$, which showed that the crystalline structural arrangement parallel to the substrate became random. As a result, this film was ascertained not to be epitaxially grown on (100) $\mathrm{MgO}$ substrate. Moreover, it was also ascertained to be made up of randomly oriented particles by SEM observation. Therefore, it is concluded that there is the upper limit of the total gas pressure for the preparation of epitaxially grown film.

\section{Conclusions}

Epitaxially grown PZT films were deposited on (100) $\mathrm{MgO}$ substrates by CVD and effects of deposition parameters on the epitaxial growth of the film were investigated. The results can be summarized as follows;

(1) The films consisting of PZT single phase were deposited from about 0.4 to 0.5 of $\mathrm{Pb} /$ $(\mathrm{Pb}+\mathrm{Zr}+\mathrm{Ti})$ and the epitaxially grown film was obtained near 0.5 of $\mathrm{Pb} /(\mathrm{Pb}+\mathrm{Zr}+\mathrm{Ti})$.

(2) Epitaxially grown PZT film was deposited at $600-700^{\circ} \mathrm{C}$ of the deposition temperature, $64 \mathrm{~Pa}-1.1$ $\mathrm{kPa}$ of the oxygen partial pressure and $1.1-6.7 \mathrm{kPa}$ of the total gas pressure.

\section{References}

1) J. S. Horwitz, K. S. Grabowski, D. B. Chrisey and R. E. Leuchtner, Appl. Phys. Lett., 59, 1565-67 (1991).

2) M. Okada, Y. Tominaga, T. Araki, S. Katayama and Y. Sakashita, Jpn. J. Appl. Phys., 29, 718-22 (1990).

3) Y. Sakashita, T. Ono, H. Segawa, K. Tominaga and M. Okada, J. Appl. Phys., 69, 8352-57 (1991).

4) K. Kashihara, H. Itoh, K. Tsukamoto and Y. Akasaka, Extend Abstract of the 1991 Int. Conf. on Solid State Device and Materials, Yokohama, Jpn. Appl. Phys. (1991) pp. 19294.

5) H. Funakubo, K. Imashita, N. Kieda and N. Mizutani, Seramikku Ronbunshi, 99, 248-50 (1991).

6) H. Funakubo, K. Imashita, K. Shinozaki and N. Mizutani, J. Ceram. Soc. Japan, 102, 114-18 (1994).

7) K. Kakegawa, J. Mohri, S. Chiba, S. Shirasaki and K. Takahashi, Nippon Kagaku Kaishi, 717-21 (1976) (in Japanese).

8) S. L. Swartz, D. A. Seifert and G. T. Noel, Thin Solid Films, 93, 37-43 (1989).

9) R. L. Holman and R. M. Fulrath, J. Am. Ceram. Soc., 55, 192-95 (1972).

10) X. Chen, H. Yamane, K. Kaya and T. Hirai, Nippon Kagaku Kaishi, 1367-72 (1991) (in Japanese).

11) K. Imashita, H. Funakubo, N. Kieda, M. Kato and N. Mizutani, Nippon Kagaku Kaishi, 1395-401 (1990) (in Japanese).

12) K. Tominaga, M. Miyagima, Y. Sakashita, H. Segawa and M. Okada, Jpn. J. Appl. Phys., 29, L1874-76 (1990).

13) R. Takayama and Y. Tomita, J. Appl. Phys., 65, 1666-70 (1989). 